\title{
Consequences of Ignoring Geologic Variation in Evaluating Grazing Impacts
}

\author{
Jonathan W. Long and Alvin L. Medina \\ Authors are Research Ecologists, Rocky Mountain Research Station, US Forest Service, \\ 2500 S Pine Knoll Dr, Flagstaff, AZ 86001.
}

\begin{abstract}
The geologic diversity of landforms in the Southwest complicates efforts to evaluate impacts of land uses such as livestock grazing. We examined a research study that evaluated relationships between trout biomass and stream habitat in the White Mountains of east-central Arizona. That study interpreted results of stepwise regressions and a nonparametric test of "grazed and ungrazed meadow reaches" as evidence that livestock grazing was the most important factor to consider in the recovery of the Apache trout (Oncorbynchus apache Miller). That study had assumed that geologic variation was insignificant in the study area. However, lithologic and topographic differences between the felsic slopes of Mount Baldy and adjacent mafic plateaus influence many attributes of trout habitat. We tested the robustness of the earlier study by using its dataset and its method of stepwise regression, but with the addition of a variable representing geologic variation. The results suggested that geology was a highly significant predictor of trout biomass $(P<0.0001)$, whereas bank damage by ungulates was not a useful predictor of residual variation in trout biomass after accounting for geology $\left(r^{2}=0.015, P=0.290\right)$. However, the associations between natural variation and land use impacts in this spatial dataset confound attempts to make inferences concerning effects of livestock grazing upon trout. Despite fundamental problems in the analysis, the results of the earlier study were repeatedly cited in scientific literature and debates about grazing management. To fairly decipher relationships between ecological production and livestock grazing in diverse landscapes requires temporal studies with reliable methodologies and proper controls for landscape variation. Ignoring geologic variation has the potential to mislead conservation policies by inappropriately implicating land use, by undervaluing inherently favorable habitats, and by inflating expectations for inherently less favorable habitats.
\end{abstract}

\section{Resumen}

La diversidad geológica de los paisajes del Sudoeste Americano complica los esfuerzos para evaluar los impactos de los usos del suelo, como el apacentamiento del ganado. Examinamos una investigación que evaluó las relaciones entre la biomasa de truchas y su hábitat ribereño en las White Mountains, de la region este-central de Arizona. Ese estudio interpretó resultados de regresión gradual y una prueba no paramétrica de "praderas apacentadas y no apacentadas," como evidencia de que el apacentamiento del ganado era el factor más importante a considerar en la recuperación de la trucha "Apache” (Oncorhynchus apache Miller). Ese estudio había asumido que la variación geológica era insignificante en el área del estudio. Sin embargo, las diferencias litológicas y topográficas entre las pendientes félsicas del Mount Baldy y las mesetas máficas adyacentes influencian muchos atributos del hábitat de la trucha. Probamos la robustez del estudio anterior usando sus datos y su método de regresión gradual, pero con la adición de una variable representando la variación geológica. Los resultados sugirieron que la geología fue un predictor altamente significativo de la biomasa de la trucha $(P<0.0001)$, mientras que el daño de las riberas por los ungulados no fue un predictor útil de la variación residual en biomasa de la trucha después de considerar la geología $\left(r^{2}=0.015\right.$, $P=0.290)$. Sin embargo, las asociaciones entre variación natural y la utilización del suelo en este juego espacial de datos confunden los intentos de hacer inferencias respecto a los efectos del apacentamineto del ganado sobre la trucha. A pesar de problemas fundamentales en el análisis, los resultados del estudio previo fueron citados repetidamente en la literatura y discusiones científicas sobre el manejo del apacentamineto. Para descifrar justamente las relaciones entre la producción ecológica y el apacentamineto del ganado en paisajes diversos, también se requieren estudios temporales con metodologías confiables y controles apropiados de la variación del paisaje. Ignorar la variación geológica tiene el potencial de conduccir erroneamente las politicas de conservación al implicar inapropiadamente la utilización del suelo, por subvaluar los hábitats intrínsecamente favorables, y por sobrevalorar las espectativas para hábitats intrínsecamente menos favorables.

Key Words: Apache trout, fish habitat, riparian areas, livestock grazing, landscape analysis, lithology

\section{INTRODUCTION}

Correspondence: Alvin L. Medina, Rocky Mountain Research Station, US Forest Service, 2500 S Pine Knoll Dr, Flagstaff, AZ 86001. Email: almedina@fs.fed.us

Manuscript received 20 October 2005; manuscript accepted 28 March 2006.
Livestock grazing has potential to indirectly impact fish populations by altering riparian and aquatic habitat in a myriad of ways (Kauffman and Krueger 1984; Platts 1991). In particular, cows and other large ungulates can shear overhanging banks, trample soils, and remove vegetative cover, 
particularly along small, fine-textured streams dominated by grassy vegetation (Trimble and Mendel 1995). Such impacts can lead to wider, shallower channels, increased streambank erosion, decreased undercuts along streambanks, and reduced streamside vegetation (Kauffman et al. 1983; Knapp and Matthews 1996). Many comparisons between ungrazed reaches and grazed reaches have suggested that such habitat modifications can diminish trout abundance (Platts 1991), although the effects can depend on how abundance is measured and can vary for different age classes (Knapp et al. 1998). Moreover, studies to determine the impacts of grazing on fishes have often been compromised by weak experimental designs (Platts 1991; Rinne 1999). Large experimental errors commonly result from high variation across and within streams, causing an inability to detect statistically significant differences (Larsen et al. 1998; George et al. 2002). Attempts to evaluate impacts of agricultural land use on fisheries have often been complicated by complex interrelationships with geologic variation at different scales (Fitzpatrick et al. 2001). Moreover, whenever land use and natural variation covary but geology and terrain are ignored, the influence of land use is likely to be overestimated (Allan 2004).

This paper reexamines a study that has been cited in literature on grazing-fish-habitat relationships to demonstrate potential effects of ignoring intermediate-scale geologic variation. We test the robustness of the earlier study by using its dataset and its method of stepwise regression, but with the addition of a variable representing geologic variation. We then trace how ignoring geology affected interpretations of the study in published reports, position statements, and articles. We explain how many of the problems in this study result from improper use of statistics, but that such errors could befall other attempts to evaluate the impacts of land uses such as livestock grazing based upon monitoring data from heterogeneous landscapes. We conclude by considering how ignoring geologic variation could ultimately mislead conservation efforts.

Apache trout (Oncorhynchus apache Miller), a species listed as threatened under the Endangered Species Act, is endemic to the White Mountains of east-central Arizona. The recovery plan for the species identified introductions of nonnative trout and habitat modifications as the 2 primary causes of declines in the species (US Fish and Wildlife Service 1983). Consequently, recovery efforts have focused on restricting nonnative trout from reaches containing pure Apache trout populations and protecting habitats by excluding grazing (Ruiz and Novy 2000). Analyses of Apache trout habitat have historically focused on a few small stream reaches (Harper 1976; Wada 1991; Kitcheyan 1999), reflecting the fact that individual streams have served as primary conservation and management units for the species. Only 1 study has evaluated trout-habitat relationships across the White Mountains region. Originally published as a report by the Arizona Game and Fish Department (Clarkson and Wilson 1991), the study was ultimately published in a major peer-reviewed fisheries journal (Clarkson and Wilson 1995). The study was 1 of only 4 data-based studies of relationships between livestock grazing and fishes in the Southwest found in the literature review by Rinne (1999). The study used stepwise regression to analyze data collected from streams on the Apache and Sitgreaves national forests and the
White Mountain Apache Reservation using a set of survey methods, the General Aquatic Wildlife System (GAWS), which had been adopted by the US Forest Service (1985). The authors of the study intended to validate the GAWS methodology and various stream habitat models that had been developed in other regions of the United States for use in the local area (Clarkson and Wilson 1991). However, they extended their results to implicate livestock management practices as a major factor limiting recovery of Apache trout habitat.

The Clarkson and Wilson study (1995) acknowledged that geology fundamentally controls aquatic habitat, stating that "fluvial habitat is largely a function of drainage basin geology and geomorphology, and thus, the generality of fish-habitat relationships is not expected to extend beyond a geologically homogeneous area" (p. 599). However, they proceeded to claim that their study area of the White Mountains was "relatively small and homogeneous." The assumption that the region was homogeneous contradicted extensive geologic research that had revealed substantial variation at the intermediate scale used in the study. A detailed map published by geologist Robert K. Merrill in 1974 showed that the White Mountains could be divided into felsic volcanic rocks (light-colored and rich in silica, with a composition like granite) and mafic volcanic rocks (dark-colored and rich in iron and magnesium, predominantly basalt). Lithologic and topographic variation influences essential aspects of salmonid habitat including base flow, substrate texture, temperature, and streambank cover (Modde et al. 1991; Nelson et al. 1992; Montgomery 1999; Rinne 2000; Hicks and Hall 2003). Moreover, geologic variation in the White Mountains is confounded with other influences on trout habitat quality, which include roads, past timber management, and use by wild ungulates such as elk (Cervus elaphus nelsoni) (Medina and Steed 2002; Long et al. 2003).

\section{METHODS}

To better understand the implications of ignoring geologic variation when evaluating trout habitat, we revisited the analyses reported by Clarkson and Wilson. Their study included 243 stations grouped into 75 reaches on 21 streams in the White Mountains that were sampled using the GAWS methodology between 1986 and 1990. We aggregated geology maps of the White Mountains area prepared by Wrucke (1961), Merrill (1974), and Nealey (1989) into an intermediate-scale map (Fig. 1). The map revealed that 6 of the study streams flow down the felsic slopes of Mount Baldy, 14 originate on adjacent mafic plateaus, and 1 flows from Escudilla Mountain, a mountain composed of mafic volcanic and volcaniclastic rock.

Clarkson and Wilson used the GAWS methodology to classify streams into reaches based upon 3 gradient types: meadow (mean gradient $<2 \%$ ), headwater (mean gradient $>6 \%$ ), and intermediate (mean gradient between $2 \%$ and $6 \%$ ). They established between 1 and 6 sampling stations within each reach; the length of each station varied from $152.4 \mathrm{~m}$ to $50 \mathrm{~m}$ depending upon the year that they were established. They established the initial stations subjectively as "representative" of the reach, and they located subsequent stations at systematically spaced intervals. Stations within reaches were located as close as $65 \mathrm{~m}$ and as far as $3000 \mathrm{~m}$ apart. They calculated 


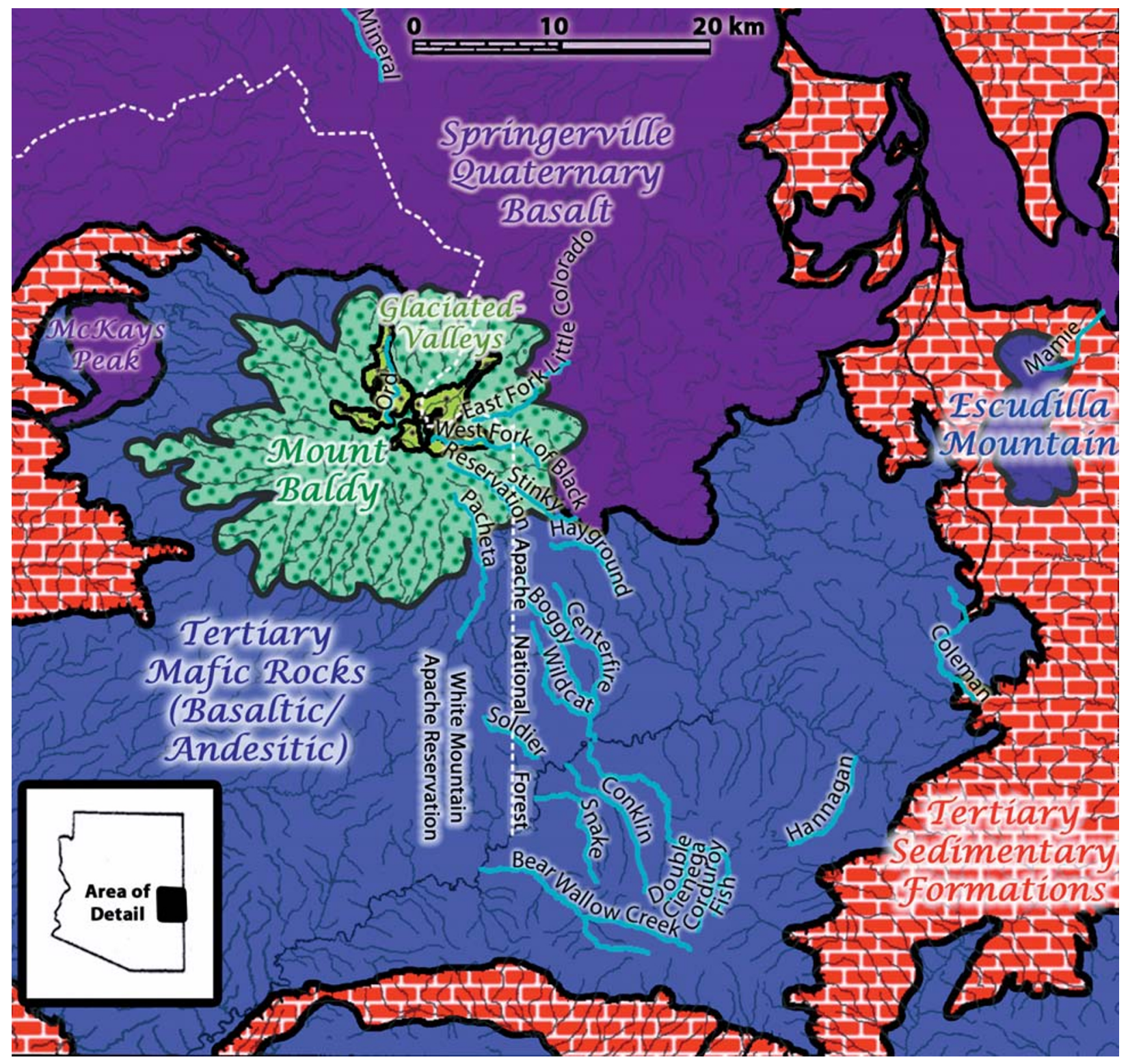

Figure 1. Geology of the White Mountains region in east-central Arizona, highlighting trout streams featured in Clarkson and Wilson (1995).

mean values for a large number of habitat variables by averaging measurements across 5 systematically placed transects within each station. The GAWS handbook (US Forest Service 1985) detailed the measurement and coding of these variables, but a more recent publication (Robinson et al. 2004) provides a convenient summary. Although many of the assessed habitat variables discussed in this paper are self-explanatory, the "ungulate bank damage rating" requires fuller explanation. The GAWS surveyors recorded bank damage by ungulates as the percent of each stream bank $5 \mathrm{~m}$ above and below each transect that appeared to have been "grazed and trampled by ungulates"; these observations were classified into 1 of 4 ratings: 4 (none to low: 0\%-25\%), 3 (moderate: $26 \%-$ $50 \%$ ), 2 (high: $51 \%-75 \%$ ), and 1 (severe: $>75 \%$ ), so that lower values represented more observed impact. The ratings did not distinguish among ungulates, although Clarkson and Wilson (1995) summarily attributed "most of the damage to domestic cattle” (p. 609).
The initial Clarkson and Wilson (1991) study employed stepwise regression starting with dozens of landscape and habitat indices in search of a model to predict trout biomass $\left(\mathrm{g} \cdot \mathrm{m}^{-2}\right)$. They reported results of a model that regressed the square root of trout biomass on 12 physical habitat variables. They noted a high degree of collinearity in their model, which, in their 1995 paper, they claimed to have remedied by removing some highly correlated explanatory variables, transforming some of the remaining variables, and "applying ridge estimates" (p. 605). The latter reference suggests that they applied ridge regression, a technique designed to improve the predictive power of regression by allowing biased estimators (Belsley et al. 1980). Their new model included ungulate bank damage rating, square root of mean channel width, natural logarithm of elevation, 2 dummy variables for channel type (distinguishing high- and intermediate-gradient reaches from low-gradient ones), natural logarithm of riparian area width, the interaction terms between elevation and the 2 channel type variables, and 
Table 1. Parameter estimates for the predictor variables in the multiple linear regression model for square root of trout biomass $\left(\mathrm{g} \cdot \mathrm{m}^{-2}\right)$ when the geology variable BaldyPercent was excluded from the analysis.

\begin{tabular}{|c|c|c|c|c|c|}
\hline Variable & $\begin{array}{c}\text { Parameter } \\
\text { estimate }\end{array}$ & $\begin{array}{c}\text { Standard } \\
\text { error }\end{array}$ & $t$ Value & $\operatorname{Pr}>|t|$ & $\begin{array}{c}\text { Variance } \\
\text { inflation } \\
\text { factor }\end{array}$ \\
\hline Intercept & 0.185 & 0.639 & 0.290 & 0.77 & 0 \\
\hline Square root of channel width & -0.508 & 0.136 & -3.75 & 0.0004 & 1.11 \\
\hline $\log _{\mathrm{e}}$ of riparian area width & 0.910 & 0.142 & 6.39 & $<0.0001$ & 1.18 \\
\hline Mean water depth & -11.2 & 2.07 & -5.39 & $<0.0001$ & 1.20 \\
\hline Ungulate bank damage rating & 0.370 & 0.137 & 2.71 & 0.0084 & 1.12 \\
\hline
\end{tabular}

mean water depth. They found all those explanatory variables to be significant except for mean water depth, and concluded that ungulate bank damage was negatively associated with trout biomass.

We could not recreate their statistical results exactly because they did not report data for each station (their basic sampling unit) in their 1991 report. However, they did provide mean values for each reach $(n=75)$, which allowed us to test the potential bias of excluding geology from their analyses. We repeated their basic technique of stepwise regression using all variables that were significant in their 1991 and 1995 "best" models and applying the same transformations that they reported in their 1995 paper. We do not recommend this statistical approach as a way to explain trout biomass; the objective of this reanalysis was simply to test how the results would change if a geology variable had been included in their analysis. To that end, we calculated the percentage of each stream reach that flowed through felsic Mount Baldy formations using our composite geology map (Fig. 1). Our specification of this new variable, BaldyPercent, reflects the fact that the attributes of streams originating in Mount Baldy formations become more like purely mafic streams as they flow downstream into mafic terrain (Long et al. 2003). We ran the stepwise regression procedure using SAS PROC REG (SAS Institute, Cary, NC) with variable selection based on a threshold significance level of 0.05 . We selected collinearity diagnostics including the variance inflation factor for each parameter and collinearity statistics with (COLLIN option) and without the intercept (COLLINOINT). We ran this procedure both excluding and including BaldyPercent from the list of possible independent variables. By examining the residuals, we found that there were no obvious violations of the assumptions of linear regression. We regressed ungulate bank damage rating on the residuals to test whether it was an important predictor after accounting for the variables selected through the stepwise regression procedure. This general approach of testing the effect of presumed anthropogenic factors after accounting for natural factors has been recommended for analyzing landscapes where anthropomorphic and natural factors are correlated (Allan 2004).

We also calculated Spearman's rank correlation coefficients between BaldyPercent and the variables that Clarkson and Wilson had used in their stepwise regression to identify variables that we would expect to be influenced by the inclusion or exclusion of BaldyPercent. This nonparametric rank correlation is appropriate because BaldyPercent has a strongly non- normal distribution in this dataset; only 14 of the 75 stream reaches represented mixtures of felsic and mafic geology. Based on the sample size of 75 in the analysis, a correlation larger in magnitude than 0.25 would be considered significant based on the single-test $P$ values with $\alpha=0.05$ (Van Sickle 2003). However, we did not provide $P$ values for the correlation coefficients because dependence among variables makes singletest $P$ values difficult to interpret (Van Sickle 2003). Instead, we applied the interpretations suggested by Franzblau (1958), in which a correlation coefficient $r>0.8$ is "high," $r$ between 0.6 and 0.8 is "marked," $r$ between 0.4 and 0.6 is "moderate," and $r$ between 0.2 and 0.4 is "low."

We also conducted simple correlation and regression analysis using data solely from Pacheta Creek (identified in Fig. 1), as a way of controlling for variation across streams. We chose this stream because it had the most sampled reaches $(n=13)$ of any in the dataset, and those reaches traversed a geologic gradient from the slopes of Mount Baldy onto the flat-lying mafic plateaus. We calculated Spearman's rank correlation coefficients between trout biomass $\left(\mathrm{g} \cdot \mathrm{m}^{-2}\right)$ and BaldyPercent, and between trout biomass and ungulate bank damage rating. We used a nonparametric statistic because both BaldyPercent and trout biomass had strongly skewed distributions. Because we were comparing a family of 2 simultaneous tests, we considered a correlation to be significantly different from zero if its $P$ value was less than 0.025 (for a familywise significance level $\alpha=0.05$ with a Bonferroni correction) (Van Sickle 2003). To account for both variables simultaneously, we regressed the square root of trout biomass $\left(\mathrm{g} \cdot \mathrm{m}^{-2}\right)$ onto BaldyPercent and ungulate bank damage rating. We applied the square root transformation to reduce heteroskedasticity in the data.

\section{RESULTS}

When BaldyPercent was not allowed to enter the model, the stepwise regression procedure fitted a model $\left(R^{2}=0.593\right.$, $P<0.0001)$ with 4 variables that Clarkson and Wilson (1995) had included in their "best" model: square root of channel width, natural logarithm of riparian area width, mean water depth, and ungulate bank damage rating (Table 1). All predictor variables in our model were significant, whereas Clarkson and Wilson (1995) had not found mean water depth to be significant. When BaldyPercent was allowed to enter the model, the stepwise regression procedure fitted a model $\left(R^{2}=0.689, P<0.0001\right)$ containing it along with mean depth, natural logarithm of riparian area width, natural logarithm of elevation, and square root of channel width (Table 2). This procedure did not select bank ungulate damage rating, indicating that it was not an important predictor of trout biomass after the other variables had been accounted for in the model. There was no significant relationship (Fig. 2; $P=0.290$ ) between bank ungulate damage rating and the residual variation in trout biomass after accounting for the physical variables in Table 2. Rank correlation coefficients (Table 3) show that BaldyPercent was markedly correlated with elevation; it was moderately correlated with riparian area width, channel width, and bank angle, and it was weakly correlated with ungulate bank damage rating, pool width, and gravel. 
Table 2. Parameter estimates for the predictor variables in the multiple linear regression model for square root of trout biomass $\left(\mathrm{g} \cdot \mathrm{m}^{-2}\right)$ when the geology variable BaldyPercent was included in the analysis.

\begin{tabular}{|c|c|c|c|c|c|}
\hline Variable & $\begin{array}{c}\text { Parameter } \\
\text { estimate }\end{array}$ & $\begin{array}{c}\text { Standard } \\
\text { error }\end{array}$ & $t$ Value & $\operatorname{Pr}>|t|$ & $\begin{array}{c}\text { Variance } \\
\text { inflation } \\
\text { factor }\end{array}$ \\
\hline Intercept & 31.6 & 10.6 & 3.00 & 0.0038 & 0 \\
\hline BaldyPercent & 0.0159 & 0.00298 & 5.34 & $<0.0001$ & 3.58 \\
\hline Mean water depth & -13.0 & 1.87 & -6.96 & $<0.0001$ & 1.27 \\
\hline $\log _{\mathrm{e}}$ of riparian area width & 0.678 & 0.134 & 5.05 & $<0.0001$ & 1.36 \\
\hline $\log _{\mathrm{e}}$ of mean reach elevation & -3.87 & 1.33 & -2.91 & 0.0048 & 3.09 \\
\hline Square root of channel width & -0.330 & 0.139 & -2.37 & 0.0204 & 1.50 \\
\hline
\end{tabular}

For the subset of 13 reaches on Pacheta Creek, rank correlation analyses indicated that trout biomass was correlated with BaldyPercent $(r=0.79, P=0.0013)$ (Fig. 3). Trout biomass was not significantly correlated with ungulate bank damage rating $(r=-0.52, P=0.076)$, although the moderately large negative coefficient suggests that more bank damage, i.e., a lower ungulate bank damage rating, was weakly associated with greater trout biomass (Fig. 4). In other words, the data suggested that headwater reaches of this creek, flowing through the Mount Baldy formations, had higher biomass than downstream reaches in the mafic plateaus, despite the fact that the upstream reaches were rated as having more ungulate damage to streambanks. The linear regression of the square root of trout biomass onto both predictor variables was significant $\left(\mathrm{R}^{2}=0.483, P=0.037\right)$, but the parameter estimates were not (Table 4). Such a result can be indicative of collinearity, although the variance inflation factors (Table 4) indicated only a modest dependency between the 2 predictor variables.

\section{DISCUSSION}

We do not interpret the results of our reanalyses as providing evidence that ungulate impacts are not an important influence

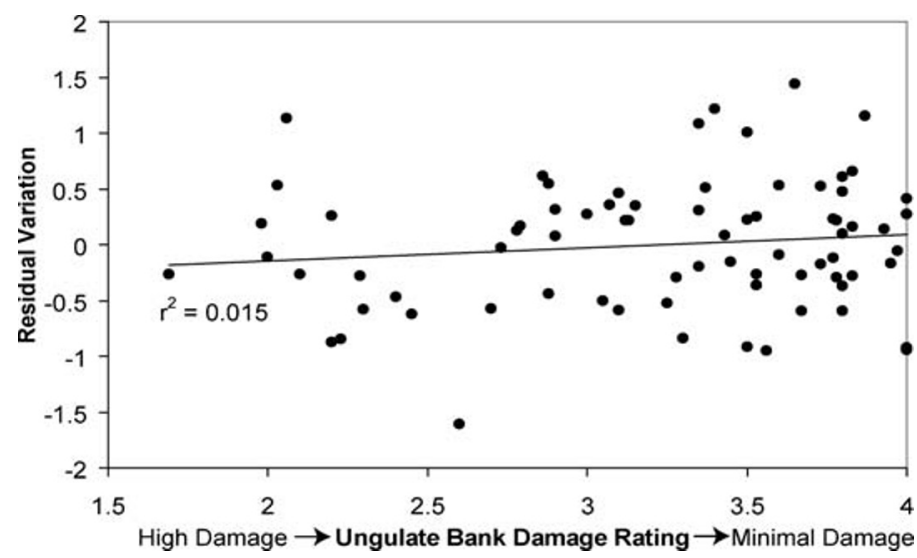

Figure 2. Scatterplot showing the lack of a relationship between ungulate bank damage rating and the remaining variation (residuals) in the square root of trout biomass $\left(\mathrm{g} \cdot \mathrm{m}^{-2}\right)$ after accounting for the landscape and channel morphology variables in Table 2.
Table 3. Spearman's rank correlation coefficients $(\rho)$ between BaldyPercent and variables that Clarkson and Wilson used in their stepwise regression procedure $(n=75)$.

\begin{tabular}{lcc}
\hline & $\begin{array}{c}\text { Spearman's } \\
\text { rank correlation } \\
\text { coefficient }(\rho)\end{array}$ & $\begin{array}{c}\text { Interpretation } \\
\text { following } \\
\text { Parameter }\end{array}$ \\
\hline Elevation & 0.821 & High \\
Bank angle & -0.593 & Moderate \\
Trout biomass & 0.531 & Moderate \\
Channel width & -0.466 & Moderate \\
Riparian area width & 0.462 & Moderate \\
Ungulate bank damage rating & 0.364 & Low \\
Gravel & 0.364 & Low \\
Pool width & -0.317 & Low \\
Gradient & -0.189 & Negligible \\
Channel type $2(2 \%-6 \%$ gradient) & -0.186 & Negligible \\
Water width & -0.181 & Negligible \\
Water depth & 0.178 & Negligible \\
Sand & 0.134 & Negligible \\
Canopy cover & -0.067 & Negligible \\
Channel type 1 gradient $)$ & -0.037 &
\end{tabular}

on trout populations and habitat, but rather we suggest that the conclusions reached in the earlier study are unreliable for several reasons. First, we consider that causal relationships between land use and habitat quality often go in 2 directions; in this case, land managers might well have decided to restrict livestock grazing on particular streams because they were unusually productive for trout. Such relationships are likely in geologically diverse regions, because geologically distinctive areas are frequently reserved for special management. On Mount Baldy, the upper watershed of the West Fork of the Little Colorado River is a federal wilderness area, and many of the headwater reaches on the White Mountain Apache Reservation are included in wilderness or other special management areas.

\section{Lurking Variables}

A central problem in the Clarkson and Wilson study was the failure to account for important variables in the study design

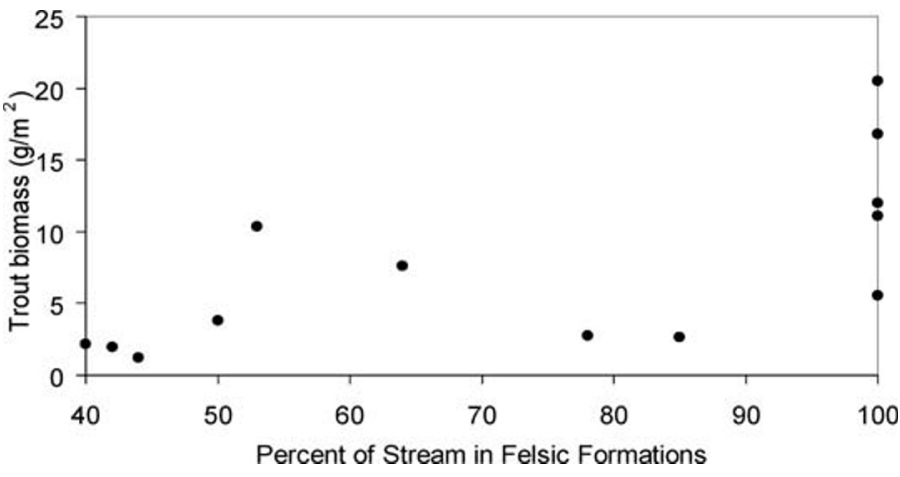

Figure 3. Scatterplot of trout biomass $\left(\mathrm{g} \cdot \mathrm{m}^{-2}\right)$ and BaldyPercent (the proportion of the stream reach that flowed through felsic formations) for 13 reaches along Pacheta Creek. 


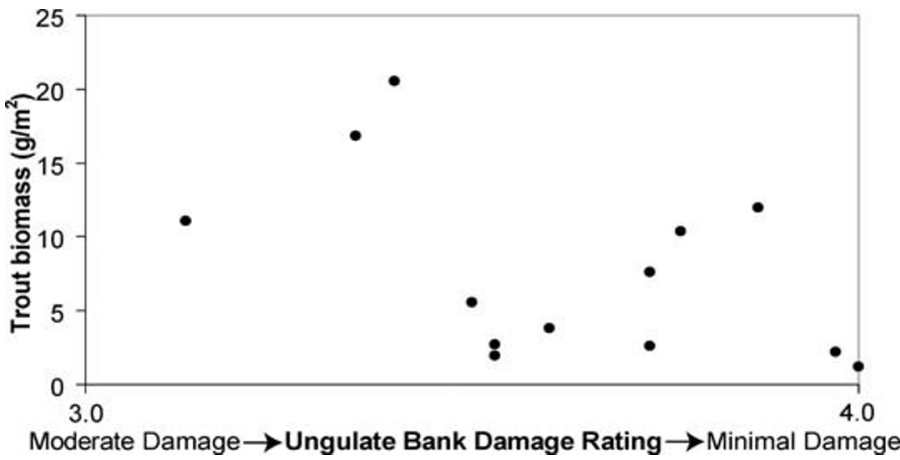

Figure 4. Scatterplot of the square root of trout biomass $\left(\mathrm{g} \cdot \mathrm{m}^{-2}\right)$ and ungulate bank damage rating for 13 reaches along Pacheta Creek. A bank damage rating of 4 represented little or no observed bank damage by ungulates; lower values represented more observed damage.

and analysis. Because of its broad influence on stream attributes, geology could account for many ecological factorsincluding substrate texture, water chemistry, topography, temperature, and baseflow-that influence trout habitat. "Illusory correlation" refers to when 2 or more variables covary because of the effects of a third "lurking" variable (Vogt 1999). Because geology was correlated with many of the variables that Clarkson and Wilson included in their analysis, one would suspect that the associations they reported could reflect an illusory correlation induced by a lurking geology variable. Clarkson and Wilson (1995) themselves suggested that "physical or chemical factors related to elevation" might have been strongly influencing trout biomass (p. 610). However, they did not consider the likelihood that ignoring those factors might alter the relationship between ungulate bank damage rating and trout biomass. Our results suggest that excluding geology from the original analysis made ungulate bank damage rating appear to be an important predictor of trout biomass.

Landscape analyses need to seek a firm understanding of the ecological relationships between the predictor and the dependent variables ( $\mathrm{Li}$ and $\mathrm{Wu}$ 2004). Such thinking should help to drop variables that are ecologically unimportant or redundant, to add missing variables that are ecologically important, and to design appropriate confirmatory analyses. Biologists might complain that geologists have not made it easy to interpret the ecological significance of geologic variation. Indeed, Merrill's work in the White Mountains was followed by more detailed petrologic studies (Nealey 1989; Condit et al. 1999) that used different terminology and generated even more complex maps. Volcanic rocks are particularly hard to classify definitively without microscopic or chemical analyses As a result, biologists face practical challenges in even recognizing geological variation, let alone accounting for it in their analyses. For instance, the GAWS handbook (US Forest Service 1985), which guided the data collection in Clarkson and Wilson's study, required identification of geological landform substrate, but the sampling form lumped felsic and mafic volcanic rocks within a single category of igneous flows. Such practical considerations may explain why Clarkson and Wilson (1995) dismissed geologic variation despite the fact that they cited Merrill's research in describing their study area.

Another variable besides geology that was missing from their analysis was species composition. Brook trout (Salvelinus
Table 4. Parameter estimates for BaldyPercent and ungulate bank damage rating in the multiple linear regression model for the square root of trout biomass $\left(\mathrm{g} / \mathrm{m}^{2}\right)$ based on data from the 13 reaches on Pacheta Creek.

\begin{tabular}{|c|c|c|c|c|c|}
\hline Variable & $\begin{array}{c}\text { Parameter } \\
\text { estimate }\end{array}$ & $\begin{array}{c}\text { Standard } \\
\text { error }\end{array}$ & $t$ Value & $\operatorname{Pr}>|t|$ & $\begin{array}{c}\text { Variance } \\
\text { inflation } \\
\text { factor }\end{array}$ \\
\hline Intercept & 2.96 & 5.10 & 0.58 & 0.575 & 0 \\
\hline BaldyPercent & 0.0263 & 0.0124 & 2.12 & 0.060 & 1.53 \\
\hline Ungulate bank damage rating & -0.649 & 1.24 & -0.52 & 0.612 & 1.53 \\
\hline
\end{tabular}

fontinalis) inhabited 4 of the 5 Mount Baldy stream reaches identified as "lightly grazed," but they occurred in only 1 of the other streams (Clarkson and Wilson 1995). Because some species may show an affinity to particular geologic units or elevation ranges, differences in trout biomass across geologic types can be confounded with species composition. For example, Stichert et al. (2001) found that brook trout were notably abundant in limestone-derived high-elevation meadow systems in Wyoming. Furthermore, different species may demonstrate different associations with habitat attributes and grazing impacts. Some models of trout-habitat relationships have failed when applied to brook trout (Shepard 1989; Modde et al. 1991), although another study found that biomass fluctuations for brook trout were greater than for most other species (Platts and Nelson 1988). Those authors interpreted their findings as indicators that brook trout were a particularly unreliable indicator of grazing impacts. Consequently, species composition is another variable that should be controlled when trying to unravel relationships among trout abundance, land use, and landscape variation.

\section{Confounded Relationships and Unrepresentative Sampling}

Even when an analysis accounts for suspected lurking variables, confounding of variables complicates attempts to determine causal relationships. Depicting the ecological setting of the dataset reveals how a strong confounding between geology and land use was embedded in this dataset. In their 1991 report, Clarkson and Wilson characterized the following streams as "lightly grazed or ungrazed": Ord Creek, upper Pacheta Creek, upper Reservation Creek, upper West Fork of the Black River, and upper East Fork of the Little Colorado River. All 5 reaches flow through the felsic and steeply sloped summit of Mount Baldy (Fig. 1). Stinky Creek was the sixth stream in their study that flows through Mount Baldy formations; although they did not mention it in their list of lightly grazed streams, it had the highest overall mean trout biomass of all the streams they examined.

Because geologic composition, elevation, and grazing are strongly associated in this landscape, the intercorrelation among variables such as BaldyPercent, natural log of elevation, and ungulate bank damage rating is not surprising. As Clarkson and Wilson pointed out in their 1991 report, collinearity among independent variables is not necessarily a problem if the objective of regression is merely to make predictions. It is for such situations, which are common in econometrics, that techniques such as ridge regression were developed (Belsley et al. 1980). However, collinearity creates major 
problems if the objective is to explain relationships between variables (Yu et al. 1999). A stepwise regression procedure may choose only one of several intercorrelated variables to enter a model. Although the failure to include the other variables may simply be an artifact of the dataset, such a result can give the impression that the excluded variables are not ecologically important.

Because geology and elevation are inherent properties of the stream reaches, it is appropriate to account for their influence before considering anthropogenic influences. Our results suggested that when we controlled for those parameters, ungulate bank damage rating did not have a strong relationship with trout biomass across the dataset. In the subset of data from Pacheta Creek, ungulate bank damage rating appeared to have a relationship to trout biomass that was opposite the one postulated by Clarkson and Wilson (Fig. 3). When both BaldyPercent and ungulate bank damage rating were included in a regression model, ungulate bank damage rating had a weak relationship with the square root of trout biomass. These results suggest that geologic variation may have greater influence on trout biomass than does ungulate bank damage rating within this dataset, but they cannot refute the broader hypothesis that ungulate grazing has negative impacts on trout. For datasets in which collinearity poses problems and the objective of analysis is to confirm a causal relationship, statistical tools such as structural equation modeling may offer a more fruitful approach (Shipley 2000).

However, any statistical analysis of this particular dataset could be prone to yielding misleading results because of confounding and the fact that samples were not collected in a representative manner with respect to grazing influences. Clarkson and Wilson (1995) explained that the steering committee for the study had decided to add 3 Mount Baldy streams because they were considered "relatively pristine," i.e., they had been "ungrazed or lightly grazed by cattle." By purposefully selecting those streams for inclusion, the study lacked the benefit of randomization to impart any confidence that those streams were representative of "ungrazed or lightly grazed" streams throughout the study area. In actuality, these additional streams were special not only because they appeared to have less use by cows, but also because they flowed through different types of land than almost all of the other streams. Although managers should seek out high quality habitats as potential references, they cannot presume that those references are valid without evidence that there are no fundamental differences between them and the other reaches to which they are being compared. For this reason, it is misleading to apply statistical analyses to samples that were not collected in a representative manner.

\section{Interpreting Exploratory Data Analyses}

Another problem is that Clarkson and Wilson made implications about livestock grazing based upon highly exploratory data analyses. Methods such as stepwise regression are designed to draw out statistical significance in the absence of a priori hypotheses; consequently, they are prone to finding spurious correlations that may be misleading (Anderson et al. 2001). A "spurious" correlation can be defined narrowly as one that is essentially an artifact of the way the data are handled
(Vogt 1999); for example, attempts to search for statistical significance among a large number of variables will often yield "statistically significant" results where none exist. This type of problem would include the failure to adjust significance levels when making a family of comparisons. Attempts to interpret tables of bivariate correlations between stream and landscape attributes frequently overstate statistical significance based upon single-test $P$ values because they fail to account for dependence among the estimated correlations (Van Sickle 2003). This problem was present in the results of both Clarkson and Wilson (1995) and in a more recent study based on similar data (Robinson et al. 2004). Searching for "interesting" or significant correlations is an instinctive practice when confronting the large quantities of spatially distributed monitoring data that agencies commonly assemble. Because of the potential for spurious correlations, such analyses need to be regarded as exploratory, not as evidence to confirm a hypothesis or support a major management policy.

The most egregious example of Clarkson and Wilson's misrepresentation of an exploratory data analysis appeared in their discussion section. They reported that "the Kruskall [sic]Wallis nonparametric test for mean comparisons indicated that the differences in mean rank of trout standing crops in grazed and ungrazed meadow reaches were highly significant $(P<0.001)$ " (p. 609). They explained that their "ungrazed meadow reaches" were found in upper Ord Creek, Pacheta Creek, and Reservation Creek, the Mount Baldy streams that had been purposefully selected for study (Clarkson and Wilson 1995). Consequently, presenting this test as a comparison between "grazed" and "ungrazed" meadow reaches contravened principles of hypothesis testing: the 2 populations being compared were not representative of grazed and ungrazed reaches, and the test did not account for any other explanatory variables, such as geology, that could explain differences in biomass. Presenting this comparison went far beyond their stated objective of testing the predictive value of the GAWS habitat assessment methodology.

\section{MANAGEMENT IMPLICATIONS}

\section{Evaluating Influences of Ungulate Grazing on Trout Habitat}

Despite the exploratory nature and flawed analyses of Clarkson and Wilson's study, its conclusions have been used to influence land management and conservation policies. Specifically, GAWS reports from the early 1990s prepared by the Arizona Game and Fish Department universally noted the low standing crops in streams on the national forests relative to reaches on the 3 Mount Baldy streams that were characterized as "lightly grazed." Such comparisons implied that the Mount Baldy streams constituted an appropriate reference. Different authors have interpreted the results of Clarkson and Wilson's study to condemn either livestock grazing in general, or heavy grazing in particular. For example, a riparian ecosystems chapter in the State of Arizona's Comparative Environmental Risk Project (Patten and Ohmart 1995) claimed that the Clarkson and Wilson (1991) study showed that "streams were either ungrazed, lightly grazed or heavily grazed, the last having sig- 
nificantly lower trout standing crop values than the first 2 categories of managed streams." The Southwest Center for Biological Diversity, an environmental organization opposed to grazing on public lands, dropped any qualifications about grazing intensity in writing that the Clarkson and Wilson (1991) study showed that "Apache trout populations in ungrazed reaches were 10 times larger than those found in grazed reaches" (Greenwald 2000). The organization repeated this claim in their petition to list the Colorado River cutthroat trout as an endangered species (Center for Biological Diversity et al. 1999). In a peer-reviewed article, Rahel and Nibbelink (1999) wrote, "In Arizona, Clarkson and Wilson (1995) reported that standing stocks of trout in streams with low gradients and suitable thermal conditions were more than twice as high in ungrazed reaches compared with grazed reaches" (p. 49). All these citations refer to the grossly inappropriate "ungrazed" versus "grazed" comparison rather than the more complex, albeit still flawed, multiple regression analysis. Readers of journal articles rely upon the peer-review process to ensure that published findings are reliable; however, these examples of misinformation demonstrate the need for users to critically evaluate the strength of evidence in a particular study, how the study accounted for natural variation, and whether the results can be extrapolated to their own ecological context.

Specific examples of channel incision and streambank alteration by ungulates have been documented for trout streams in the White Mountains (Neary and Medina 1996; Medina and Long 2004). However, those examples as well as others attributed to "unmanaged grazing" have not established an unequivocal relationship between managed livestock grazing and diminished trout production across such a diverse landscape as the White Mountains. Researchers at the Arizona Game and Fish Department (Robinson et al. 2004) recently analyzed some of the same GAWS survey data used by Clarkson and Wilson, along with additional GAWS surveys, from a subset of 6 White Mountains streams that flow only through mafic plateaus. They did not find a significant relationship between ungulate bank damage rating and Apache trout biomass or density, although they also relied on exploratory correlation analyses. Moreover, other studies have suggested that geology mediates the relationship between ungulate influences and trout populations. For example, sandy and gravelly riparian soils are often less vulnerable to ungulate-induced bank erosion than are finer-textured soils (Nelson et al. 1992; George et al. 2002). Furthermore, Knapp et al. (1998) reported that grazing increased numbers of golden trout in a felsic (granitic) meadow system by creating more suitable spawning habitat. Both of these examples suggest that trout habitat in the felsic, gravel-rich formations of Mount Baldy might be less likely to exhibit negative impacts from grazing than in more finely textured mafic plateaus.

\section{Designing Research and Monitoring Studies}

Efforts to understand the relationships between livestock grazing and fish in the Southwest are confounded by longitudinal (upstream-downstream) interactions and temporal dynamics, as well as by natural variation associated with geology (Rinne 1999). Many variables used to evaluate stream habitat, such as substrate quality, pool depths, and frequency of large woody debris, are linked both to natural landscape variation and to changes in land use (Hicks and Hall 2003; Medina et al. 2005). Consequently, attempts to use such variables as indicators of ecosystem health without controlling for natural variation run a serious risk of making erroneous inferences. Because the influences of geology on fish habitat are complex, analyses should not assume that relationships will follow a predictable pattern across a diverse landscape. Instead, studies need to stratify by landscape type and examine changes through time due to treatments relative to controls in comparable areas (Rinne 1999). Conducting temporal studies with valid controls is particularly important for evaluating causal relationships. The high cost of such studies may deter researchers and managers from designing experiments to fairly evaluate the effects of grazing on fishes. However, researchers and managers also need to consider the costs of attributing differences in habitat quality across a varied landscape to livestock grazing or other land uses in the absence of confirmatory studies.

Attempts to evaluate effects of livestock grazing should use methodologies that yield reliable measures of impacts that are ecologically meaningful to the species of concern. The GAWS methodology evaluates both grazing and trampling impacts through a single, qualitative rating of ungulate bank damage. Consequently, it provides a less precise and objective measure of ungulate impacts on trout habitat than do monitoring approaches that quantitatively measure bank shearing and trampling and separately measure other attributes that could be affected by ungulates including protective cover, vegetative composition, stubble height, woody species utilization, and woody species regeneration (Cowley and Burton 2005; Medina et al. 2005). Studies that use more reliable methodologies should impart greater confidence that they have demonstrated causal relationships rather than illusory correlations.

\section{Making Conservation Policies}

Clarkson and Wilson (1995) argued that "bank damage by ungulates was the variable most readily affected by land management practices and thus the most important variable for managers to consider in recovery of Apache trout or enhancement of trout populations in general" (emphasis ours; p. 609). Their emphasis on livestock grazing could mislead Apache trout conservation efforts by diverting attention from other factors, such as wild ungulates, past road construction, logging impacts, and introduction of exotic species, which have been associated with declines in Apache trout populations (US Fish and Wildlife Service 1983; Neary and Medina 1996; Medina and Steed 2002). Because their analysis did not consider those other impacts, their implication that grazing was the most important land use factor was essentially a foregone conclusion.

Recognition that streams may be marginal because of natural geologic and climatic conditions would promote more efficient use of conservation resources. Streams in the mafic areas may require far greater investment to create suitable trout habitat because of less reliable baseflows, limited influxes of gravels, and an abundance of nonnative streamside vegetation associated with mafic areas (Medina and Steed 2002; Long et al. 2003). This argument challenges the claim by Clarkson and Wilson (1991) that, "trout streams in the White Mountains area and others within the Gila Mountain Ecoregion in general, 
represent fisheries resources of unparalleled productive potential if habitat restoration is allowed to proceed" (p. 33). A recent temporal study of several White Mountains streams in mafic areas found that biomass was greater before than after fencing to exclude livestock grazing (Robinson et al. 2004). Noting that many sections of their study streams had gone dry after fencing, the authors concluded that any positive effects on Apache trout populations by excluding livestock were overshadowed by drought. Another study found that reaches on 3 mafic streams identified for recovery of Apache trout (Boggy, Centerfire, and Wildcat Creeks, Fig. 2) repeatedly went dry over a 7-year period, confounding efforts to determine relationships between trout populations and ungulate impacts (Medina and Steed 2002). These studies suggest that streams in purely mafic areas of the White Mountains are often marginal, and they demonstrate the need to prioritize high-quality habitats for conservation of Apache trout.

Failure to account for geologic influences on habitat quality tends to shift attention away from inherently higher-quality streams. For example, an amendment to the Apache-Sitgreaves National Forests Plan (US Forest Service 1989) called for maintaining fines in riffle areas below $20 \%$ and a "Biotic Condition Index" (based on the relative abundance of macroinvertebrates associated with fine sediment) above a particular threshold in Apache trout habitats. Such application of uniform standards and policies to diverse landscapes may be common (Rhodes et al. 1995). It has the effect of drawing attention to marginal streams that lie close to the standards, while being insensitive to possible degradation of high-quality streams that remain above the standards. As another example of implied uniformity, current standards for recovery of Apache trout focus on the absolute number of populations and the total length of occupied streams reaches (Ruiz and Novy 2000). Such standards do not create an incentive to favor stream reaches that have more stable base flows and can support larger trout populations, even though viability of threatened trout populations is likely tied to the absolute numbers of spawning fish (Rieman and Allendorf 2001). If the standards were modified to account for natural variation in habitat quality, then recovery efforts might give greater weight to extending the range of pure Apache trout within drainages on Mount Baldy. Instead, recovery efforts have emphasized introducing the species into predominantly mafic areas (Ruiz and Novy 2000).

Geologic variation can have important and complex influences on the quality of habitat for fish populations. Managers and researchers need to recognize that failure to properly account for such variation could lead to improper implication of land use and inefficient conservation policies. Such failures could also undermine conservation efforts by fostering resentment and cynicism among local people who have long recognized the importance of local variations in their ecosystems.

\section{ACKNOWLEDGMENTS}

Two anonymous reviewers and an associate editor suggested revisions that substantially improved and clarified previous versions of this manuscript. We thank Leslie Hartsell, John Rinne, Mitchel White, and several anonymous reviewers for their comments on early drafts of this manuscript. We thank Rudy King for reviewing our statistical analyses and interpretations. Any errors remain ours.

\section{LITERATURE CITED}

Allan, J. D. 2004. Influence of land use and landscape setting on the ecological status of rivers. Limnetica 23:187-198.

Anderson, D. R., K. P. Burnham, W. R. Gould, and S. Cherry. 2001. Concerns about finding effects that are actually spurious. Wildlife Society Bulletin 29:311-316.

Belsley, D. A., E. Kuh, and R. E. Welsch. 1980. Regression diagnostics: Identifying influential data and sources of collinearity. New York, NY: John Wiley and Sons. $292 \mathrm{p}$.

Center for Biological Diversity, The Biodiversity Legal Foundation, Biodiversity Associates, Ancient Forest Rescue, Southwest Trout, Wild Utah Fort Campaign, Center for Native Ecosystems, and Colorado Wild. 1999. Petition to list the Colorado River cutthroat trout (Oncorhynchus clarki pleuriticus) as a threatened or endangered species under the U.S. Endangered Species Act. Available at: http://www.biologicaldiversity.org/swcbd/papers/CRCTintro.html. Accessed 15 March 2006.

Clarkson, R. W., and J. R. Wilson. 1991. Evaluation of the U. S. Forest Service Fish Habitat Relationship System in east-central Arizona trout streams. Phoenix, AZ: Arizona Game and Fish Department. Technical Report 8. 39 p.

Clarkson, R. W., AND J. R. WiLson. 1995. Trout biomass and stream habitat relationships in the White Mountains area, east-central Arizona. Transactions of the American Fisheries Society 124:559-612.

Condit, C. D., L. S. Crumpler, and J. C. Aubele. 1999. Lithologic age-group, magnetopolarity, and geochemical maps of Springerville volcanic field, eastcentral Arizona (1:100,000). Denver, CO: US Geological Survey. Geologic Investigations Series I-2431.

Cowley, E. R., and T. A. Burton. 2005. Monitoring streambanks and riparian vegetation-multiple indicators. Boise, ID: US Department of the Interior Bureau of Land Management. Technical Bulletin No. 2005-02. 29 p.

Fitzpatrick, F. A., B. C. Scudder, B. N. Lenz, and D. J. Sullivan. 2001. Effects of multi-scale environmental characteristics on agricultural stream biota in eastern Wisconsin. Journal of the American Water Resources Association 37:1489-1508.

Franzblau, A. N. 1958. A primer of statistics for non-statisticians. New York, NY: Harcourt, Brace and World. $150 \mathrm{p}$.

George, M. R., R. E. Larsen, N. K. McDougald, K. W. Tate, J. G. Gerlach, and K. 0. Fulgham. 2002. Influence of grazing on channel morphology of intermittent streams. Journal of Range Management 55:551-557.

Greenwald, N. 2000. Protection and conservation of southwest native trout. Available at: http://www.sw-center.org/swcbd/papers/trout.htm. Accessed 15 March 2006.

HARPER, K. C. 1976. On the biology of Salmo apache and its management implications [thesis]. Tucson, AZ: University of Arizona. $44 \mathrm{p}$.

Hicks, B. J., AND J. D. HaLl. 2003. Rock type and channel gradient structure salmonid populations in the Oregon Coast Range. Transactions of the American Fisheries Society 132:468-482.

Kauffman, J. B., and W. C. Krueger. 1984. Livestock impacts on riparian ecosystems and streamside management implications ... a review. Journal of Range Management 37:430-438.

Kauffman, J. B., W. C. Krueger, and M. Vavra. 1983. Impacts of cattle on streambanks in northeastern Oregon. Journal of Range Management 36: 683-685.

Kitcheyan, D. C. 1999. Population structure of Apache trout (Oncorhynchus apache) in Flash and Squaw creeks on the Fort Apache Indian Reservation, Arizona [thesis]. Tucson, AZ: University of Arizona. 143 p.

Knapp, R. A., and K. R. Matthews. 1996. Livestock grazing, golden trout, and streams in the Golden Trout Wilderness, California: impacts and management implications. North American Journal of Fisheries Management 16:805-820.

Knapp, R. A., V. T. Vredendurg, and K. R. Matthews. 1998. Effects of stream channel morphology on golden trout spawning habitat and recruitment. Ecological Applications 8:1104-1117.

Larsen, R. E., W. C. Krueger, M. R. George, M. R. Barrington, J. C. Buckhouse, and D. E. Johnson. 1998. Viewpoint: livestock influences on riparian zones and fish habitat: literature classification. Journal of Range Management 51:661-664. 
LI, H., AND J. Wu. 2004. Use and misuse of landscape indices. Landscape Ecology 19:388-399.

Long, J. W., A. TeCLe, and B. M. Burnette. 2003. Geologic influences on recovery of riparian wetlands on the White Mountain Apache Reservation. Journal of the Arizona-Nevada Academy of Science 35:46-60.

MedinA, A. L., And J. W. Long. 2004. Placing riffle formations to restore stream functions in a wet meadow. Ecological Restoration 22:120-125.

Medina, A. L., J. N. Rinne, and P. Roni. 2005. Riparian restoration through grazing management: considerations for monitoring project effectiveness. In: P. Roni [ED.]. Methods for monitoring stream and watershed restoration. Bethesda, MD: American Fisheries Society. p 97-126.

Medina, A. L., AND J. E. Steed. 2002. West Fork Allotment riparian monitoring study 1993-1999. Final Project Report, Volume 1. Flagstaff, AZ: US Department of Agriculture, Forest Service, Rocky Mountain Research Station. $177 \mathrm{p}$.

MerRiLL, R. K. 1974. The late Cenozoic geology of the White Mountains, Apache County, Arizona [dissertation]. Tucson, AZ: Arizona State University. 202 p.

Modde, T., R. C. Ford, and M. G. Parsons. 1991. Use of a habitat-based stream classification system for categorizing trout biomass. North American Journal of Fisheries Management 11:305-311.

Montgomery, D. R. 1999. Process domains and the river continuum. Journal of the American Water Resources Association 35:397-410.

Nealey, L. D. 1989. Geology and petrology of the Late Cenozoic Mount Baldy trachytic volcanic complex, White Mountains volcanic field, Apache and Navajo counties, Arizona [dissertation]. Albuquerque, NM: University of New Mexico. 320 p.

Neary, D. G., and A. L. Medina. 1996. Geomorphic response of a montane riparian habitat to interactions of ungulates, vegetation, and hydrology. In: D. W. Shaw and D. M. Finch [EDS.], Desired future conditions for Southwestern riparian ecosystems: Bringing interests and concerns together. 18-22 September 1995; Albuquerque, NM. Fort Collins, CO: US Department of Agriculture, Forest Service, Rocky Mountain Forest and Range Experiment Station. p. 143-147.

Nelson, R. L., W. S. Platts, D. P. Larsen, and S. E. Jensen. 1992. Trout distribution and habitat in relation to geology and geomorphology in the North Fork Humboldt River Drainage, northeastern Nevada. Transactions of the American Fisheries Society 121:405-426.

Patten, D. T., and R. D. Ohmart. 1995. Arizona's riparian ecosystems. In: M. Collins and J. McHenry [EDS.]. Ecosystems of the Arizona Comparative Environmental Risk Project. Chapter 1, Section 2. Available at: http://earthvision.asu.edu/ acerp/section2/Chp_01ES.html. Accessed 15 March 2006.

PLATTS, W. S. 1991. Livestock grazing. In: W. R. Meehan [ED.]. Influences of forest and rangeland management on salmonid fishes and their habitats. Bethesda, MD: American Fisheries Society. p 389-423

Platts, W. S., and R. L. Nelson. 1988. Fluctuations in trout populations and their implications for land-use evaluations. North American Journal of Fisheries Management 8:333-345.

Rahel, F. J., AND N. P. NibBelink. 1999. Spatial patterns in relations among brown trout (Salmo trutta) distribution, summer air temperature, and stream size in Rocky Mountain streams. Canadian Journal of Fisheries and Aquatic Sciences 56:43-51.
Rhodes, B. J., C. B. Marlow, and H. W. Sherwood. 1995. Monitoring streambank stability: grazing impacts or stream variability? Montana Agresearch 12:3-8.

Rieman, B. E., and F. W. Allendorf. 2001. Effective population size and genetic conservation criteria for bull trout. North American Journal of Fisheries Management 21:756-764.

RinNE, J. N. 1999. Fish and grazing relationships: the facts and some pleas. Fisheries 24:12-21.

RinNE, J. N. 2000. Effects of substrate composition on Apache trout fry emergence. Journal of Freshwater Ecology 16:355-365.

Robinson, A. T., L. D. Avenetti, and C. Cantrell. 2004. Evaluation of Apache trout habitat protection actions. Phoenix, AZ: Research Branch, Arizona Game and Fish Department. Technical Guidance Bulletin 7. 19 p.

RUIz, L. D., AND J. R. Novy. 2000. Recovery status of Apache trout Oncorhynchus apache. In: D. Schill, S. Moore, P. Byorth, and P. Hamre [EDS.]. Wild Trout VII Symposium: Management in the New Millennium, are we ready? 1 October 2000; Bozeman, MT. Bozeman, MT: Montana State University. p 155-160.

ShePARD, B. B. 1989. Evaluation of the U. S. Forest Service COWFISH model for assessing livestock impacts on fisheries in the Beaverhead National Forest, Montana. In: R. E. Gresswell, B. A. Barton, and J. W. Kirchner [eds.]. Practical approaches to riparian resource management, an educational workshop, 8 May 1989; Billings, MT. Billings, MT: US Bureau of Land Management. p 23-33.

SHIPLEY, B. 2000. Cause and correlation in biology: A user's guide to path analysis, structural equations and causal inference. Cambridge, UK: Cambridge University Press. $317 \mathrm{p}$.

Stichert, N. D., W. A. Hubert, and Q. D. Skinner. 2001. A test of factors hypothesized to influence biomass of salmonids in Rocky Mountain streams. Journal of Freshwater Ecology 16:493-500.

Trimble, S. W., And A. C. Mendel. 1995. The cow as a geomorphic agent-a critical review. Geomorphology 13:233-253.

US Fish and WILdLIfe Service. 1983. Recovery plan for Arizona trout, Salmo apache Miller 1972. Special report, revised. Albuquerque, NM: US Fish and Wildlife Service. $38 \mathrm{p}$.

US FoREST SeRVICE. 1985. Fisheries habitat survey handbook. Ogden, UT: US Forest Service, Region 4. FSH 2609.23. 400 p.

US Forest SeRVICE. 1989. Apache-Sitgreaves National Forests plan. Amendment 1. Washington, DC: US Government Printing Office. 278 p.

VAN SICKLE, J. 2003. Analyzing correlations between stream and watershed attributes. Journal of the American Water Resources Association 39:717-726.

VoGT, W. P. 1999. Dictionary of statistics \& methodology: A nontechnical guide for the social sciences. Thousand Oaks, CA: Sage Publications. $318 \mathrm{p}$.

WADA, L. L. L. 1991. Summer habitat use by Apache trout (Oncorhynchus apache) in five streams on the Fort Apache Indian Reservation [thesis]. Tucson, AZ: University of Arizona. $62 \mathrm{p}$.

Wrucke, C. T. 1961. Paleozoic and Cenozoic rocks in the Alpine-Nutrioso area, Apache County, Arizona. Reston, VA: US Geological Survey. Bulletin 1121-H. $26 \mathrm{p}$.

Yu, C. H., D. Winograd, S. Andrews, S. Digangi, and A. Jannasch-Pennell. 1999. Visualizing collinearity, variance inflation factor, and orthogonalization in subject space. In: 1998 Proceedings of the Section on Statistical Education, 12 August 1998; Alexandria, VA. Alexandria, VA: American Statistical Association. p 119-124. 